\title{
SALAM ATAU SELOMITA: \\ TINJAUAN SASTRA DAN MASYARAKAT
}

\author{
Eva Farhah \\ evafarhah@staff.uns.ac.id
}

Program Studi Sastra Arab, Fakultas Ilmu budaya, Universitas Sebelas Maret

\begin{abstract}
This research aims to find out the social phenomenon in short story untitled Salam aw Selomita (1983). These phenomena are seen as a personification of activities or facts related to the setting of society, particularly Palestine society in which the short story takes place. The short story consists the continuing conflict and permanent battle in Palestine society that can provide for the readers several valuable social phenomena. Hence the short story was intended one of conveying aspiration means for present society. This research uses the theory of the sociology of literature as a subfield viewing literary facts as a reflection of society, an empirical reality experienced by Palestine society, and uses the method by revealing events that experienced by Palestine society represented by actor Salam or Selomita, a reflection of social facts in current Palestine society. The research's results show that the social phenomenon in the short story untitled Salam or Selomita is kidnapping the Palestinians children conducted by colonialist. The kidnapping has left a deep grief and tears for the parents and the Palestinians.
\end{abstract}

Keywords: Sociology of literarure, The short story Salam aw Selomita, Palestine, Israel.

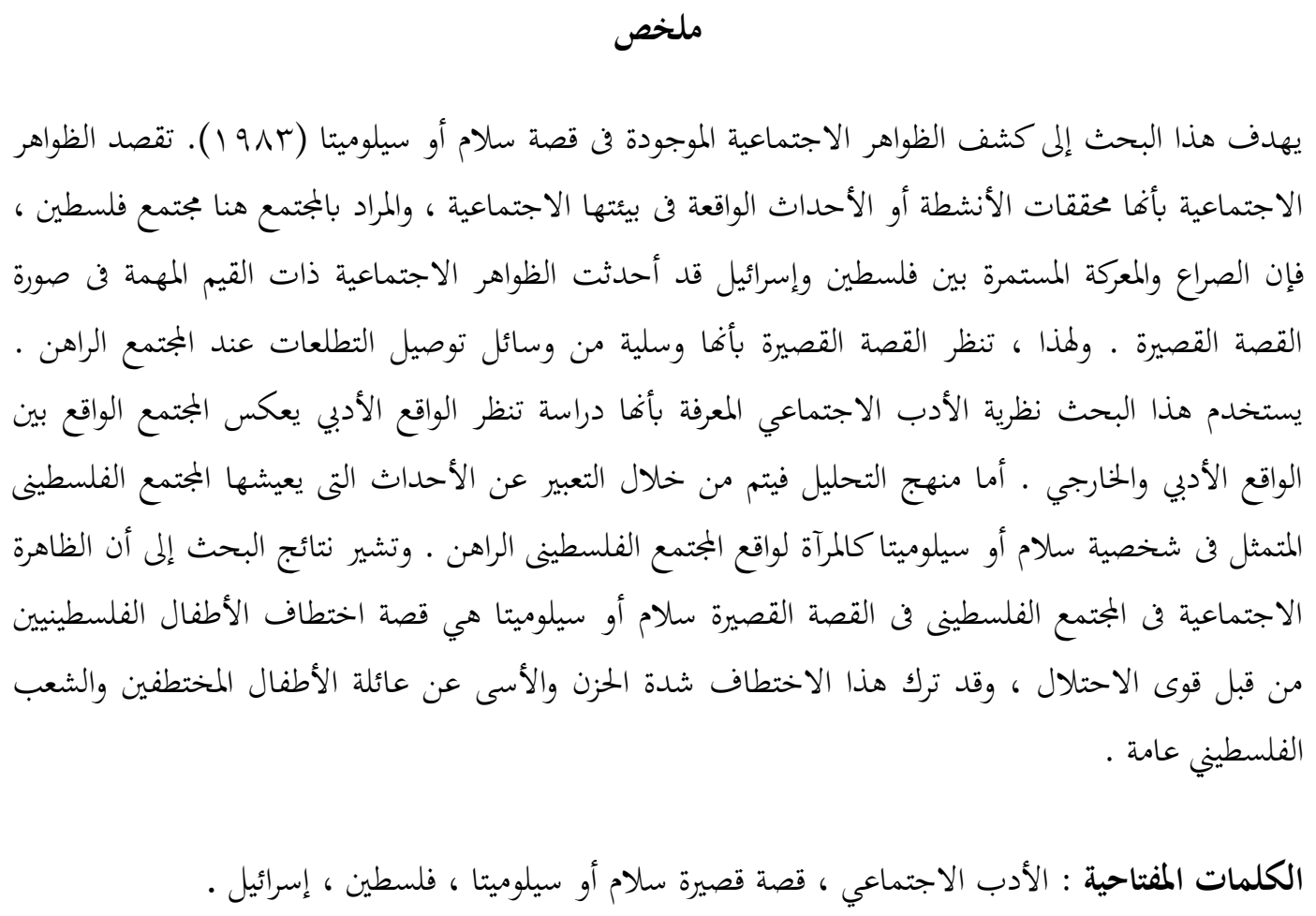




\section{PENDAHULUAN}

Sastra dapat dipandang sebagai suatu gejala sosial. Sastra yang ditulis oleh pengarang pada suatu kurun waktu tertentu pada umumnya langsung berkaitan dengan norma-norma dan adat istiadat jaman itu (Luxemburg, 1984:23). Sastra yang baik tidak hanya merekam kenyataan yang ada dalam masyarakat seperti sebuah tustel foto, tetapi merekam dan melukiskan kenyataan sosial secara totalitas. Aspek terpenting dalam kenyataan yang perlu dilukiskan oleh pengarang yang dituangkannya dalam karya sastra adalah masalah kemajuan manusia dan berbagai masalah yang dihadapinya. Karena itu, pengarang yang melukiskan kenyataan sosial secara totalitas tidak dapat mengabaikan begitu saja dengan masalah-masalah tersebut. Dia harus mengambil sikap dan melibatkan diri dalam masyarakat karena dia juga termasuk salah satu anggota masyarakat (Luxemburg, 1984:28). Karya sastra merupakan tanggapan penciptanya (pengarang) terhadap dunia (realita sosial) yang dihadapinya. Di dalam sastra berisi pengalaman-pengalaman subjektif penciptanya, pengalaman subjektif seseorang (fakta individual atau fakta libidinal) ataupun pengalaman sekelompok masyarakat (fakta sosial). Oleh karena itu, karya sastra bukanlah sesuatu yang sederhana, sesuatu yang selesai atau tuntas yang hanya mempunyai satu kemungkinan tafsir saja. Akan tetapi, dia adalah ekspresi seluruh kehidupan si pencipta (pengarang), dan karena itulah karya seni adalah sama kompleksnya seperti manusia sendiri (Budiman, 1976:7-8).

Dari tanggapan pencipta (pengarang) terhadap dunia sekelilingnya (realitas sosial) yang diwujudkan dalam bentuk karya sastra, maka kiranya dapat dikatakan bahwa karya sastra merupakan pembayangan atau pencerminan realitas sosial. Karya sastra yang dihasilkan oleh pencipta (pengarang) merupakan sastra yang kompleks, karena dia berada dalam jaringan-janngan sistem dan nilai dalam
masyarakat.Pencipta

(pengarang) melahirkan karya sastra yang berwujud novel atau lainnya merupakan manifestasi sosial. Manifestasi sosial yang berwujud karya sastra tidaklah lahir dengan cara yang sederhana, tetapi dia lahir dengan cara pencipta (pengarang) terlebih dahulu melakukan analisis datadata yang ada dalam kehidupan masyarakat, menginterpretasikan, mencoba menetapkan tanda-tanda penting, dan kemudian mengubahnya dalam bentuk tulisan (karya sastra). Dengan demikian, yang harus diperhatikan oleh pencipta (pengarang) adalah bahwa karya sastra harus dilahirkan dari sebuah observasi yang rasional dan pengalaman pencipta (pengarang) dari sebuah realitas sosial (istilah WS Rendra Manjing ing Sajroning Kahanan). Artinya, sebelum pencipta (pengarang) menulis karya sastra yang berwujud novel atau lainnya, maka ia terlebih dahulu menganalisis sebuah realitas sosial yang dihadapinya (Zeraffa, 1973:35). Seorang pencipta (pengarang) yang berkualitas tentunya dapat melihat perkembangan masyarakat secara keseluruhan sehingga persepsinya terhadap realitas sosial yang dituangkan di dalam karyanya dapat mencerminkan realitas sosial yang sesungguhnya. Tentunya, persepsi pengarang terhadap realitas sosial yang telah dituangkan dalam bentuk karya sastra merupakan sastra yang kompleks sehingga perlu ditafsirkan dengan cermat dan hati-hati. Dengan perkataan lain, sastra adalah bagian dari masyarakat yang dihasilkan oleh pengarang yang dia sendiri adalah salah satu anggota kelompok masyarakatnya. Oleh karena itu, latar belakang sosial pengarang dan lingkungannya yang perlu diperhatikan apabila sastra dinilai sebagai cermin masyarakat.Karya sastra diciptakan oleh sastrawan untuk dinikmati, dipahami, dan dimanfaatkan oleh masyarakat. Dia terikat oleh status sosial tertentu sehingga masyarakat menjadi salah satu pembentuk sastra. 
Sastra adalah lembaga sosial yang menggunakan bahasa sebagai mediumnya, dan bahasa itu sendiri merupakan ciptaan sosial. Sastra menampilkan gambaran kehidupan, dan kehidupan itu sendiri adalah suatu realitas sosial. Dalam pengertian ini, kehidupan mencakup hubungan antar masyarakat, antara masyarakat dengan orang-seorang, antar-manusia, dan antarperistiwa yang terjadi dalam batin seseorang, semuanya itu yang sering menjadi bahan sastra adalah pantulan hubungan seseorang dengan orang lain atau dengan masyarakat (Damono, 1979:1). Hal ini sebagaimana tampak dalam cerita pendek berjudul Salam aw Selomita karya Yagi, 1983. Melalui cerita ini, pengarang mengungkapkan fenomena sosial yang terjadi pada suatu masyarakat. Untuk itulah, tujuan dari penelitian ini adalah mengungkapkan kondisi sosial masyarakat Palestina dan kekejaman yang menimpanya. Untuk mengungkapkan kondisi sosial dan kekejaman yang menimpa masyarakat Palestina, dimanfaatkan teori sosiologi sastra dan metodenya.

Sastra dapat dipandang sebagai suatu fenomena sosial. Sastra ditulis dalam kaitannya dengan norma-norma dan adat istiadat jaman itu. Dengan demikian, sastra yang dihasilkan oleh seorang pengarang yang adalah salah satu anggota masyarakat merupakan refleksi sosial. Keadaan sosial selalu ditandai dengan pertentangan kelas, dan seorang penulis (pengarang) akan menyuarakan kelasnya masing-masing. Kesan tentang pertentangan kelas ini akan ditemui juga dalam karya sastra sehingga tokoh-tokoh yang ada di dalamnya merupakan tokoh-tokoh yang representatif yang mewakili kelas sosial tertentu.

Kritik sastra Marxis, khususnya teorinya tentang materialisme historis dan dialektik mengatakan bahwa susunan masyarakat dalam bidang ekonomi, yang dinamakan bangunan bawah (kaum Proletar) menentukan kehidupan sosial, politik intelektual, dan kultural bangunan atas (kaum Borjuis). Perubahan bangunan bawah dapat mengakibatkan perubahan dalam bangunan atas sehingga pertentangan kaum Proletar dan kaum Borjuis dapat menuju kepada revolusi yang dapat menghancurkan sistem kapitalis. Kaum Proletar yang jaya akan melaksanakan masyarakat tanpa kelas.

Lenin yang dapat dipandang sebagai peletak dasar bagi kritik sastra Marxis berpendapat bahwa di dalam susunan masyarakat terdapat hubungan timbal-balik (hubungan dialektik) antara bangunan bawah dan bangunan atas (dengan Catatan secara historis, bahwa akhimya bangunan bawahlah yang selalu menentukan). Selanjutnya, dikatakan oleh Lenin bahwa sastra (dan seni pada umumnya) merupakan suatu sarana penting dalam perjuangan proletariat melawan kapitalisme. Dengan demikian, sastra terikat akan kelas-kelas yang ada di dalam masyarakat dan sastra mencerminkan kenyataan sebagai ungkapan pertentangan kelas (Luxemburg, 1984:24-25).

Telah disebutkan di atas bahwa seorang penulis (pengarang) akan menyuarakan kelasnya masing-masing sehingga akan terjadi apa yang dinamakan committed literature atau litterature engagee (sastra yang berpihak). Gagasan litterature engagee timbul sebagai akibat dari pengaruh ideologi modern terhadap kesusastraan. Semuanya ini akan mencerminkan perubahan sosial yang tepat dan mendasar pada jamannya (Damono, 1979:53).

Oleh karena terjadi litterature engagee (sastra yang berpihak), maka akan lahir wajah sastra yang bermacammacam tergantung pada setiap pengarang yang melahirkan sastra tersebut, karena dia juga termasuk salah satu anggota kelompok sosialnya. Dari sinilah akan diketahui fungsi sosial sastra pada masing-masing kelompok sosialnya. Fungsi sastra yang akan dilahirkannya pun wujudnya bermacam-macam, karena 
wajah sastra yang telah dilahirkan juga bermacam-macam. Untuk melihat fungsi sosial sastra yang bermacam-macam itu, maka tergantung dari kelas masyarakat mana sastra itu dilahirkan dan dari mana si peneliti memandangnya. Misalnya, sastra yang dilahirkan oleh seorang pengarang dari bangunan masyarakat bawah (kaum proletar), maka fungsi sosial sastra sebagai sarana perjuangan proletariat melawan sistem kapitalisme. Jika sastra itu dilahirkan oleh pengarang dari bangunan masyarakat atas (kaum borjuis), maka fungsi sosial sastra sebagai sarana untuk melegitimasi kaum borjuis sehingga sistem kapitalisme semakin kokoh. Jika sastra dilahirkan oleh pengarang-pengarang sufi yang persepakatnya mengalami kegoncangan kejiwaan (misalnya pengarang Maulana Jalaluddin Rumi), maka fungsi sosial sastra adalah sebagai sarana untuk menuntun kehidupan masyarakat dalam bidang kerohaniannya. Dengan demikian, fungsi sosial sastra itu tergantung dari masyarakat mana sastra itu dilahirkan, karena sastra adalah bagian dari masyarakat, dan masyarakat menjadi salah satu pembentuk sastra. Sastra ditulis oleh pengarang yang adalah anggota kelompok sosial masyarakatnya dan sastra berada dalam jaringan-jaringan sistem dan nilai dalam masyarakat. Oleh karena itu, langkah awal yang harus segera dikerjakan oleh penelitian sosiologi sastra adalah menentukan jenis masyarakat yang melahirkan sastra sehingga dapat diketahui sifat-sifat masyarakat yang melahirkan sastra tersebut dan dengan mudah fungsi sosial sastra pun juga dapat diketahui. Yang menjadi persoalan justru adalah bagaimana jika sastra itu tidak mencerminkan realitas sosial (bertolak belakang dari kenyataan).

Tentang sastra yang tidakmencerminkan realitas sosial itu adalah salah satunya disebabkan oleh pengarang yang tidak mampu melukiskan gambaran sosial dalam karyanya yang sesuai dengan kenyataan, atau mungkin juga disebabkan oleh pengarang sendiri yang sengaja melukiskan gambaran sosial dalam karyanya yang bertolak belakang dengan kenyataan sosial, karena mungkin ada sesuatu yang dicitacitakan oleh pengarangnya; atau mungkin pengarang ingin membuat suatu inovasi tertentu(Daudy, 1978:7; 1990:28). Secara teknik dan metodologis sangat sulit untuk menentukan fungsi sosial sastra yang sastra itu sendiri tidak mencerminkan realitas sosial. Memang sastra sangat kompleks seperti halnya manusia, tetapi sangat menarik dan menyenangkan untuk dibicarakan khususnya dari visi sosiologi sastra sebagaimana diungkapkan oleh Al-Hakim (1981).

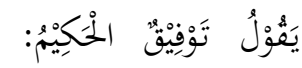

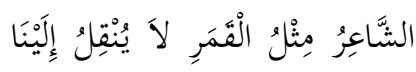

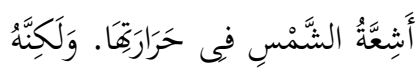

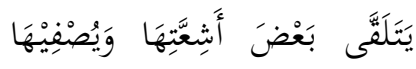

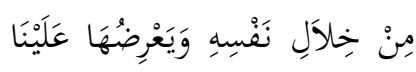

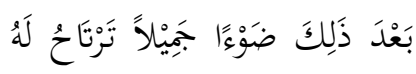

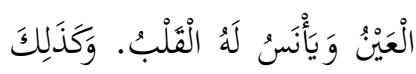

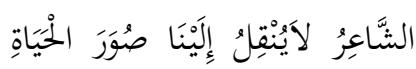

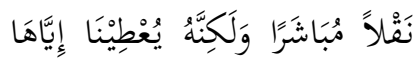

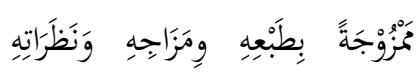

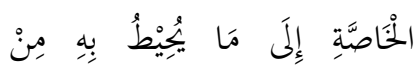

$$
\begin{aligned}
& \text { كَائَنَاتِ }
\end{aligned}
$$

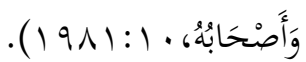

$$
\begin{aligned}
& \text { Taufiq Al-Hakim } \\
& \text { (dalam Shaqr dkk, } \\
& \text { 1981:10) mengatakan: } \\
& \text { "Penyair itu seperti bulan, } \\
& \text { tidak memancarkan } \\
& \text { cahaya panas matahari } \\
& \text { kepada kita, tetapi } \\
& \text { mengambil sebagian } \\
& \text { sinarnya dan menyerapnya } \\
& \text { ke dalam dirinya, lalu } \\
& \text { memancarkannya kembali }
\end{aligned}
$$


kepada kita dalam bentuk cahaya yang indah yang menyejukkan mata dan menyenangkan hati. Demikian hal ya penyair, tidak menyampaikan fenomena kehidupan secara langsung kepada kita (pembaca), tetapi menyampaikannya dalam suatu bentuk yang telah diolah oleh subjektivitas pengarang dan pandangan dunianya secara alami (genetik) yang diambil dari realitas sosial masyarakat tempat pengarang tinggal.

Dengan demikian, melalui penelitian ini ditemukan fenomenafenomena sosial yang terekam dalam karya sastra, yaitu cerita Salam aw Selomita. Penentuannya sebagai objek penelitian karena kehadiran karya sastra merupakan hal yang dapat menggugah kesadaran manusia lain (pembaca)untuk dapat merasakan keprihatinan masyarakat Palestina yang hidup dalam situasi dan kondisi yang mencekam, membantu menyuarakan perdamaian bagi masyarakat Palestina dan alasan kongkrit lainnya adalah karena di dalamnya menampilkan peristiwa-peristiwa yang dialami, dirasakan, dan dipikirkan oleh manusia dalam kehidupannya (bdk. Sangidu, 2004:2;63). Selanjutnya, penelitian mengenai fenomena-fenomena sosial yang terdapat dalam kisah Salam aw Selomita berdasarkan hasil menelusuran peneliti belum ditemukan. Dengan demikian, penelitian ini dapat menggugah sisi kemanusiaan masyarakat pembaca atas fenomena sosial yang terdapat di Palestina.

\section{PEMBAHASAN}

Untuk mengungkap kejadian penculikan seorang anak gadis bernama Salam atau Selomita yang terdapat di dalam cerpen Salam atau Selomita dalam kaitannya dengan sastra sebagai cerminan dari realita social, dapat dikemukakan di bawah ini, yaitu sebagai berikut.

\section{Kondisi Sosial Masyarakat Palestina}

Pada bagian ini diuraikan secara singkat kondisi sosial masyarakat Palestina berikut ini. Secara geografis, Palestina adalah sebuah wilayah yang terletak di Rimur Tengah antara Laut Tengah dan Sungai Yordania. Terletak di lokasi yang strategis di antara Mesir, Suriah dan Jazirah Arab, wilayah ini memiliki sejarah yang panjang sebagai persimpangan bagi agama, budaya, perdagangan dan politik. Bangsa Palestina atau orang Palestina adalah orang-orang Arab dari Tepi Barat dan Jalur Gaza, yang disebut juga sebagai wilayah Palestina (id.wikipedia.org/wiki/Palestina, diunduh pada sabtu, 17/03/2018, pukul 21.47). Dengan demikian, istilah Palestina adalah suatu nama suatu daerah geografi atau etnis bangsa yang memiliki sejumlah interpretasi; pertama (orang) Palestina, kedua, negara Palestina, ketiga, Otoritas Nasional Palestina, dan keempat, Organisasi Pembebasan Palestina.

Kondisi sosial masyarakat Palestina diliputi oleh suasana yang bergejolak sejak terjadinya deklarasi Balfour pada tahun 1917. Deklarasi publik yang dikeluarkan oleh pemerintah Britania saat Perang Dunia I yang isinya mengumumkan dukungan untuk mendirikan tanah air bagi orang Yahudi di Palestina, yang saat itu merupakan wilayah kekuasaan Utsmaniyah dengan populasi minoritas Yahudi. Inilah awal mula terjadinya konflik antara Palestina dan Israel, tepatnya di akhir abad ke-19 sampai dengan tahun 1920 (id.wikipedia.org/wiki/ Konflik_IsraelPalestina, diunduh pada sabtu, 17/03/2018, pukul 22.43). Dalam perkembangannya, masyarakat Palestina semakin gigih dalam memperjuangkan tanah airnya dengan dibentuknya Organisasi Pembebasan Palestina (PLO) 
pada mei 1964. Perjuangan masyarakat Palestina semakin bergejolak, meskipun di saat-saat tertentu terkadang meredup dan terkadang meledak. Panjangnya waktu yang dihabiskan untuk berperang melawan musuh-musuhnya semakin menyulut semangat Palestina untuk membebaskan diri dari berbagai kemelut. Hal ini ditunjukkan oleh masyarakat Palestina dengan cara melakukan Perjanjian Nasional Palestina di tahun 1968. Dalam perjanjian ini, Palestina besikap tegas dan secara resmi menuntut pembekuan Israel.

\section{Pengungsian Palestina}

Setelah dilakukan Perjanjian Nasional Palestina di tahun 1968, keaadaan masyarakat Palestina jauh dari kondisi yang baik. Hal ini terbukti dengan terjadinya perang di tahun 1970 . Setelah itu, di tahun 1973 meletus perang Yom Kippur. Keadaan demikian membuat negara-negara Arab turut berusaha medamaikan negara bertikai. Seperti yang telah dilakukan Mesir, yaitu Kesepakatan Damai Mesir-Israel di Camp David 1978. Namun kesepakatan damai ini tidak membuahkan hasil sebagaimana yang diharapkan. Hingga akhirnya terjadi perang Libanon pada tahun 1982. Peperangan ini terjadi dengan alasan adanya usaha pembunuhan atas duta besar Israel, Shlomo Argov.

Pada saat peperangan berlangsung, kondisi Libanon mejadi tempat pengungsian bagi kurang lebih 110.000 pengungsi Palestina pasca terjadinya perang antara Arab dan Israel di tahun 1948. Selain itu juga, Libanon selatan dijadikan pangkalan untuk penyerangan-penyerangan terhadap Israel. Dalam pengungsian ini, masyarakat Palestina tinggal di sebuah pemukiman di sebut dengan Sabra. Yaitu sebuah pemukiman miskin yang terletak di pinggiran selatan Beirut Barat. Wilayah Sabra bersebelahan dengan kamp pengungsi Shatilla yang dibangun pada tahun 1949. Selama bertahun-tahun masyarakat dari kedua wilayah ini semakin bercampur, sehingga menjadi satu istilah baru "kamp Sabra dan Shatilla". Dari tahun ke tahun, masyarkatnya semakin membengkak, bertambah banyak karena kedatangan pengungsi-pengungsi Palestina dan Syiah dari selatan yang menyelamatan diri dari peperangan

(id.wikipedia.org/wiki/Pembantaian_Sabr a_dan Shatilla, diunduh pada hari sabtu, 17/03/2018, pukul 23:39).

Dalam keadaan peperangan dan hidup dalam pengungsian, masyarakat Palestina, khususnya anak-anak bermain di jalan-jalan tidak jauh dari tempat tinggalnya sebagaimana yang diceritakan dalam Salam aw Selomita.

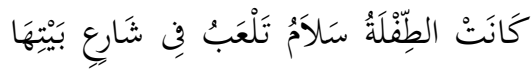

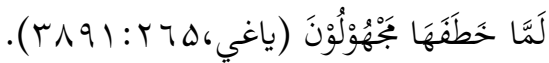

$$
\begin{aligned}
& \text { Salam, seorang gadis } \\
& \text { kecil, sedang bermain di } \\
& \text { jalan depan rumahnya } \\
& \text { ketika orang-orang tak } \\
& \text { dikenal menculiknya } \\
& \text { (Yaghi, 1983: 265). }
\end{aligned}
$$

Penculikan anak Palestina kerap terjadi dari dahulu semenjak peperangan hingga saat ini. Meraka di culik tidak jauh dari tempat-tempat tinggal orang tuanya. Penculikan tidak saja terjadi di tempat-tempat tersembunyi, bahkan terjadi di tempat umum dan terbuka, seperti yang terjadi pada seorang anak bernama Muhammad Abu Khudair (17 tahun)

www.panjimas.com/news/2014/07/05/te ntara-israel-kembali-menculik-anakpalestina-rekaman-cctv-penculikanmuhammad-abu-khudair diunduh pada hari minggu, 18/03/2018, pukul 00.24). Penculikan ini terjadi di berbagai wilayah pemukiman Palestina seperti di kota Yarussalem, Hebron dan tempat pemukiman lainnya sebagimana yang ditampakkan dalam data tekstual tersebut di atas.

Data tekstual di atas menginformasikan bahwa telah terjadi penculikan atas seorang gadis kecil 
bernama Salam. Penculikan dilakukan oleh sekelompok orang-orang dan dilakukan dengan cepat. Salam diculik saat dia sedang bermain di jalan depan rumahnya. Anak-anak Palestina bermain di jalan-jalan atau gang depan rumahnya, sedangkan penculik dapat dipastikan menyusup ke dalam perkampungan pemukian Palestina untuk melaksanakan aksinya. Penculikan ini tidak diketahui motifnya, karena mayoritas anak-anak Palestina yang diculik kemudian ditemukan beberapa hari kemudian sudah dalam keadaan tidak bernyawa. Beberapa anak-anak Palestina lainnya yang telah diculik dikemablikan ke tempat asal mereka saat diculik sebagaimana yang terjadi pada 2(dua) orang anak yang sedang bermain di seberang pemukiman Karmi Zur, saat tidak ada bentrokan antara Israel dan warga Palestina, namun tiba-tiba 2(dua) tentara Israel muncul di belakang anak-anak Palestina dan kemudian membawa ke markas pangkalan militer Israel untuk diinterogasi. Setelah 10 jam lamanya mereka di sekap dan diinterogasi serta di pandang tidak membahayakan tentara Israel, akhirnya tentara Israel kembali mengantarkan anak-anak tersebut hingga pintu gerbang desa pemukimannya, tetapnya pada pukul 03.00 dini hari (kasihpalestina.com/2017/10/13/kisahpenculikan-anak-palestina-oleh-pasukanisrael).

Kedua kisah penculikan anak Palestina tersebut di atas mengalami kasus yang berbeda. Dapat diamati dan disimpulkan, bahwa jika anak Palestina tersebut dipandang membahayakan tentara Israel atau melawan tentara Israel, maka si anak akan dibunuh. Akan tetapi, ketika posisi si anak saat di interograsi tidak membahayakan tentara Israel atau dipandang oleh tentara Israel jawaban si anak tidak menyudutkan posisi Israel, maka si anak akan dibebaskan kembali. Kedua kisah ini berbeda dengan kisah tokoh Salam dalam Salam aw Selomita. Dalam kisah ini, tokoh Salam di culik, kemudian di sembunyikan dan tidak dikembalikan kepada orang tuanya. Dalam tempat persembunyian Salam, si penculik menyukai Salam. Dia menganggapnya seperti boneka, sehingga rambut salam disepuh dengan warna keemasan dan kedua matanya dipasang lensa mata yangberwarna biru. Ini merupakan penculikan dengan motif yang beda dari kisah penculikan anak yang pernah terjadi sebelumnya.

Setelah terjadi penculikan, kedua orang tua Salam mencari-cari informasi dan melaporkan diri kepada kepolisian setempat untuk memberikan ciri-ciri Salam. Kabar ini pun disebarkan ke kantor-kantor polisi diberbagai wilayah Palestina agar Salam dapat segera ditemukan. Hal ini tampak pada data tekstual di bawah ini.

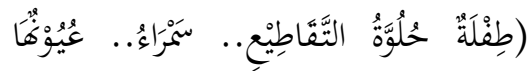

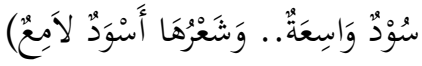

$$
\begin{aligned}
& \text { هَذِِْ هِيَ الْمُوَاصَفَاتُ الَّتِى عُمِّمَتْ عَلَّى }
\end{aligned}
$$

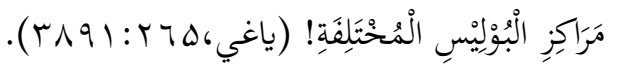

$$
\begin{aligned}
& \text { "Gadis kecil } \\
& \text { manisparasnya . . . } \\
& \text { berkulit coklat . . . } \\
& \text { bermata hitam dan lebar. } \\
& \text {. . berambut hitam } \\
& \text { berkilau" } \\
& \text { Ini adalah ciri-ciri yang } \\
& \text { disebarkan ke kantor- } \\
& \text { kantor polisi di berbagai } \\
& \text { tempat! (Yaghi, } \\
& \text { 1983:265). }
\end{aligned}
$$

Data tekstual tersebut di atas menjelaskan usaha-usaha yang dilakukan oleh orang tua Salam. Meraka melaporkan kehilangan salam saat bermain di jalanan dekat rumahnya, menginformasikan ciri-ciri yang terdapat pada salam seperti gadis kecil, berkulit coklat, bermata hitam lebar dan berambut hitam berkilauan. Laporan tentang kehilangan Salam-pun disebarkan ke kantor-kantor polisi yang tersebar di wilayah kekuasaan Palestina agar Salam 
segera dapat ditemukan dan dapat berkumpul kembali dengan orang tuanya.

Seiring berjalannya waktu, beberapa informan yang tidak diketahui asalnya, dari pihak Palestina ataupun dari pihak Israel yang menyamar sebagai warga Palestina memberikan informasi yang simpang siyur. Maskipun demikian, Salam tidak juga ditemukan atau dikembalikan oleh penculik. Keadaan ini dapat dilihat pada data tekstual berikut ini.

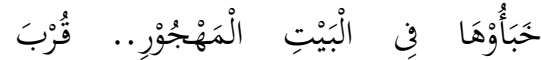

$$
\begin{aligned}
& \text { الثَّاطِى }
\end{aligned}
$$

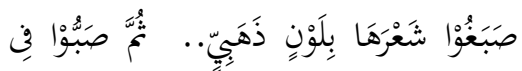

$$
\begin{aligned}
& \text { عَيْنَيْهَا صِبْغَغَة زَرْقَاءَ. } \\
& \text {... }
\end{aligned}
$$

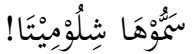

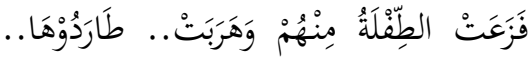

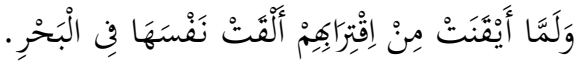

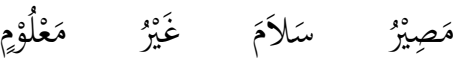

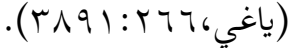

Mereka menyembunyikannya di rumah terasing ... dekat pantai.

Mereka menyepuh rambutnya dengan warna keemasan . . . lalu mewarnai kedua matanya dengan warna biru.

Kemudian ...

Mereka menamainya, Selomita!

Gadis kecil itu takut pada mereka dan lari ... Mereka mengejarnya . . Ketika menyadari kalau orang-orang yang mengejarnya telah dekat, ia menceburkan diri ke laut!

Tak diketahui apa yang terjadi pada Salam (Yaghi, 1983:266).

Berdasarkan kabar yang tesebar, bahwa Salam telah disembunyikan oleh para penculik di sebuah rumah yang terasing dari jangkauan masyarakat, lokasi rumah tersebut di dekat pantai. Untuk menyamarkan keberadaan Salam dalam wilayah rumah dekat pantai tersebut, para penculik menyepuh rambutnya dengan warna keemasan, sehingga tertutuplah warna kilau hitam pada rambutnya yang dahulu, mamasangi lensa mata yang berwarna biru pada bola matanya yang hitam sehingga hilanglah ciri-ciri Salam yang bermata hitam. Kemudian hal lain yang dipandang menyimpang jauh dari diri Salam adalah kini Salam di panggil dengan panggilan Selomita. Para penculik mengganti nama Salam dengan Selomita.

Aksi ini dilakukan oleh para penculik karena rasa sukanya kepada Salam. Dengan berbagai cara mereka menutupi jati diri Salam dan menjadikannya seorang Selomita. Dalam satu atau dua kesempatan, aksi yang dilakukan oleh para penculik dapat menyelamatkan diri Salam dari para kawanan penculik lainnya, karena Salam dianggap sebangsa dengan para penculik sehingga tidak akan disakiti. Akan tetapi, dalam keadaan yang lain, diri tokoh Salam tetap merasa asing ketika hidup dan tinggal bersama para penculik. Rasa takut Salam terhadap para penculik pun tetap meliputi dirinya. Sehingga, ketika para penculik mencoba mendekatinya dan meraihnya, dia berlari menghindar dan menceburkan diri ke laut. Sampai pada peristiwa ini, kemudian informasi tentang keadaan Salam atau Selomita tidak diketahui lagi.

Setelah informasi tentang Salam atau Selomita tersebut menyebar luas di tengah-tengah masyarakat, muncul kembali informasi lain dari sejumlah informan sebagaimana dapat dilihat pada data tekstual di bawah ini.

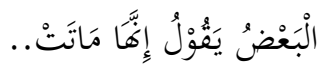

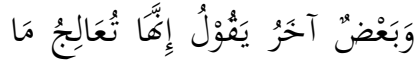

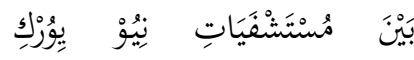

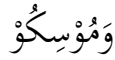

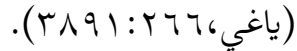

Sebagian orang berkata, dia telah mati ... 
Yang lain berkata, dia sedang diobati di salah satu rumah sakit antara New York dan Moskow (Yaghi, 1983:266).

Kabar simpang siyur lainnya yang disampaikan oleh para informan terkait keadaan Salam atau Selomita adalah Salam telah meninggal dunia di laut setelah dikejar oleh para penculik. Sedangkan sebagaian informan lainnya memberikan informasi bahwa Salam atau Selomita tidak meninggal dunia, dia hanya mengalami luka-luka sehingga perlu dilarikan ke salah satu rumah sakit yang ada di antara New York dan Moskow. Setelah sejumlah informasi tentang Salam atau Selomita tersebut berkembang dan menyebar, kemudian informasi itu meredup. Tidak ada informasi lebih lanjut lagi mengenai Salam atau Selomita.

\section{Posisi Pengarang}

Seorang pencipta

(pengarang)yang berkualitas dapat melihat perkembangan masyarakat secara keseluruhan. Dengan kata lain, pengarah adalah orang yang menuturkan tentang kehidupan. Sebagaimana halnya Abdurrahman Yaghi di dalam bukunya yang berjudul Fil-adabil-FalastiniyyilChadîts: Qablan-Nakbah wa Ba'daha (1983), dia mengungkapkan kisah Salam aw Selomita secara runtut hingga akhir kisah

https://www.alwatanvoice.com/arabic/ne ws/2017/03/23/1031594.html\#

ixzz5AJ6Dr37S, diunduh pada hari Rabu, tanggal 21/03/2018, pukul 22:42. Dia mengetahui informasi semenjak Salam diculik, kemudian di sembunyikan di sebuah rumah, perubahan-perubahan yang terjadi dalam diri Salam mulai dari rambutnya di sepuh warna pirang keemasan hingga bola matanya berwarna biru, sampai dengan perubahan nama Salam menjadi Selomita. Setelah itu, dia juga mengetahui bahwa Salam melarikan diri dengan cara menceburkan dirinya ke laut, hingga informasi terakhir pun, tentang Salam meninggal dunia atau di rawat di rumah sakit yang berada di antara New York dan Moskow. Melalui uraian tersebut, posisi pengarang jelas tampak mengetahui perkembangan masyarakatnya. Karya sastra yang diciptakannya berfungsi sebagai sarana untuk membantu masyarakat Palestina yang semakin hari semakin tertindas dan tidak diketahui bagaimana nasib masa depannya, maka sastrawan berusaha membantu meringankan perjuangan Palestina lewat karya-karya sastra.

Perhatian dan pengamatan pengarang pun tidak cukup berhenti sampai pada informasi-informasi tentang Salam atau Selomita saja, tetapi juga tertuju pada orang tua dan masyarakat lainnya. Sebagaimana yang dinyatakan dalam data tekstual berikut ini.

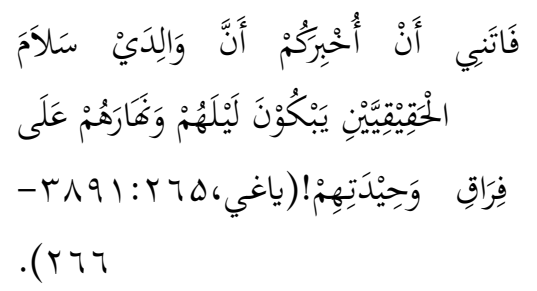

Akhirnya, kukabarkan kepada Anda sekalian bahwa kedua orang tua Salam menangis siang malam karena kehilangan putri tunggalnya itu! (Yagi, 1983: 266).

Data tekstual tersebut di atas menjelaskan bahwa sang pengarang memberikan informasi kepada para pembaca mengenai kedua orang tua Salam atau Selomita. Kedua orang tua Salam bersedih dan menangis atas kehilangan putri satu-satunya. Salah satu sifat manusiawi adalah bersedih dan menangis atas kehilangan putri tunggalnya. Di sini lain, tampak kesungguhan pengarang untuk membantu meringankan beban penderitaan keluarga dan masyarakat Palestina. Sebagai salah satu anggota masyarakat Palestina, seorang petinggi dalam kementerian 
kebudayaan Palestina, kritikus, sastrawan, pendidik, dan peneliti, dia tidak menghendaki kisah serupa akan muncul kembali di masa-masa yang akan mendatang

http://alqudslana.com/index.php?action=i ndividual_details\&id=2457, diunduh pada hari Rabu, tanggal 21/03/2018, pukul 22:50. Melalui kisah Salam atau Selomita, secara tidak langsung pengarang menginformasikan kepada masyarakat pembaca bahwa agar orang tua selalu memperhatikan dan menjaga putra dan putrinya dalam situasi dan kondisi apa pun.

\section{SIMPULAN}

Dari uraian di atas dapat dikemukakan bahwa cerpen berjudul Salam atau Selomita di atas merupakan ekpresi Abdurrahman Yaghi berdasarkan pengamatannya secara langsung yang terjadi pada masyarakat Palestina. Untuk itulah, dengan karyanya tersebut dimaksudkan agar dapat menggugah perasaan pembaca untuk berfikir apa yang sebenarnya telah terjadi di tanah Palestina. Selanjutnya, dengan caranya masing-masing pembaca akan berusaha sekuat tenaga untuk membantu meringankan penderitaan yang dialami masyarakat Palestina.

Pemecahan persoalan sosial yang dialami oleh masyarakat Palestina perlu digulirkan lewat karya sastra karena sudah tidak ada lagi cara lain yang dapat digunakan, baik oleh siapa pun yang menaruh perhatian terhadap kesengsaraan masyarakat Palestina maupun oleh pengarang yang ada di Palestina ataupun di luar Palestina. Hal yang demikian dilakukan oleh pengarang Abdurrahman Yaghi untuk mendobrak dan melawan penjajah yang dengan kejam dan bengisnya selalu membuat masyarakat Palestina dalam keadaan sengsara dan hidupnya tidak menentu.

Pesan atau message tajam yang disampaikan oleh Abdurrahman Yaghi kepada para pembacanya dapat memacu dan mendorong masyarakat dunia guna memberikan jalan keluar penyelesaian konflik yang terjadi di Palestina. Selain itu, pesan atau message tersebut dapat dipahami dan dirasakan oleh para pembacanya karena Abdurrahman Yaghi telah terlibat langsung dan melakukan pengamatan langsung pada masyarakat Palestina yang sedang mengalami konflik dan penderitaan yang berkepanjangan dan sampai saat ini belum ada penyelesaiannya. Dengan perkataan lain, apa yang dialami dan dirasakan oleh masyarakat Palestina juga dialami dan dirasakan oleh Abdurrahman Yaghi karena sebagai pengarang, ia terlibat langsung dengan cara Manjing ing Sajroning Kahanan.

Untuk itulah, lewat cerpen berjudul Salam aw Selomita, Abdurrahman Yaghi dapat menghidupkan fungsi sosial sastra terhadap masyarakat, baik masyarakat kelas bawah (masyarakat terjajah) maupun kelas atas (masyarakat penjajah). Kedua kelompok masyarakat tersebut pada gilirannya diharapkan dapat menyadari dirinya masing-masing bahwa kehidupan di dunia sebaiknya saling tolong menolong, dan bukan sebaliknya saling menjajah atau yang kuat menjajah yang lemah.

\section{DAFTAR PUSTAKA}

\section{Buku}

Budiman, Arif. 1976. Choiril Anwar Sebuah Pertemuan. Pustaka Jaya, Jakarta.

Damono, Sapardi Djoko. 1979. Sosiologi Satsra Sebuah Pengantar Ringkas.Jakarta:Pusat Pembinaan dan Pengembangan Bahaia Deparlemen Pendidikan dan Kebudayaan.

Daudy, Ahmad. 1978. Syaikh Nuruddin Ar-Raniri (Sejarah, Karya, dan Sanggahan terhadap Wujudiyah di Aceh).Jakarta: Bulan Bintang.

Luxemburg, Jan van. 1984. Pengantar 
Ilmu Sastra diindonesiakan oleh Dick Hartokodari judul asli Inleiding in de literatuurwetenschap. Jakarta: PT Gramedia.

Sangidu, 2004. Penelitian Sastra: Pendekatan, Teori, Metode, Teknik, dan Kiat. Unit Penerbitan Sastra Asia Barat, Fakultas Ilmu Budaya: Yogyakarta.

Shaqr, Ahmad Muhammad Wa ashchâbihi. 1981. Al-Adhwâ'u fillughatil 'Arabiyyah bâbul balâghah.Dârun Nahdhah: Mishr al-Qâhirah.

Yagi, Abdurrahman,1983, Fil-adabilFalastiniyyil-Chadits: QablanNakbah wa Ba'daha, cetakan pertama. Syirkah lin-nasyri wattauzî‘ wat-tarjamah: Kuwait.

Zeraffa, Michel. 1973. The Novel as Literary Form and as Social Institution dalam

Elizabeth and Tom Burns Sociology Literature \& Drama. C.Nicholls \&Company Ltd.: Great Britain.

\section{Website}

id.wikipedia.org/wiki/Palestina, diunduh pada sabtu, 17/03/2018, pukul 21.47 .

id.wikipedia.org/wiki/Konflik_IsraelPalestina, diunduh pada sabtu, 17/03/2018, pukul 22.43.

id.wikipedia.org/wiki/Pembantaian_Sabra _dan Shatilla, diunduh pada hari sabtu, 17/03/2018, pukul 23:39.

www.panjimas.com/news/2014/07/05/tent ara-israel-kembali-menculik-

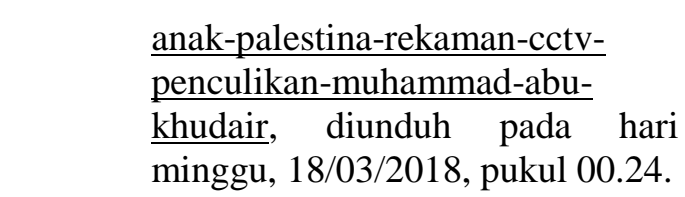

kasihpalestina.com/2017/10/13/kisahpenculikan-anak-palestina-olehpasukan-israel.

https://www.alwatanvoice.com/arabic/ne ws/2017/03/23/1031594. html\#ixzz5AJ6Dr37S, diunduh pada hari Rabu, tanggal 21/03/2018, pukul 22:42.

http://alqudslana.com/index.php?action=i ndividual_details\&id=2457. diunduh pada hari Rabu, tanggal 21/03/2018, pukul 22:50. 